\begin{tabular}{|l|l|} 
Jurnal Bimbingan dan Konseling Ar-Rahman \\
Volume 4, Nomor 1,Tahun 2018 \\
Tersedia Online: http://ojs.uniska.ac.id/index.php/BKA \\
e-ISSN 2477-6300
\end{tabular}

\title{
CORE CURRICULUM MANAGEMENT BASED AUTHENTIC INSTRUCTIONAL MODEL
}

Caraka Putra Bhakti, Fuad Aminur Rahman, Muhammad Alfarizqi Nizamuddin Ghiffari

Universitas Ahmad Dahlan

E-mail: caraka.pb@bk.uad.ac.id/085235761213

\begin{abstract}
The purpose of this paper is as a reference model of core curriculum management services with the instructional authentic model. core curriculums are one of the most important services to be delivered to today's students. core curriculums aim to optimize the potential of today's students. Optimization of student potential can be realized if service, implementation and service evaluation can be done by school counselor optimally. This is closely related to management, which in general management is the ability to manage things to achieve certain goals. From this, the core curriculum which as part of the education needs to be resolved or has good management. Obviously, manage core curriculum need to attend to appropriate model and development of students. In core curriculum, Management model authentic instructional model. This model is a pedagogical approach which puts in the context of the future. From this model, the core curriculums provided to students oriented toward students and up to date. This will help school counselors continue to innovate and develop core curriculums applied to students. It is hoped that through this model, school counselors can plan and develop and become an evaluation material for themselves in developing a core curriculum.
\end{abstract}

Kata Kunci: Management, Core Curriculum, Authentic Instructional Model

Dipublikasikan Oleh :

UPT Publikasi dan Pengelolaan Jurnal

Universitas Islam Kalimantan Muhammad Arsyad Al-Banjari Banjarmasin 


\section{INTRODUCTION}

Management is a series of all activities that refer to cooperative efforts between two or more people to achieve a predetermined goal (Suharsimi \& Yuliana, 2012: 3). Management in a profession is a necessity because basically, the management will give effect to human resources. Therefore to be a professional is a demand for occupation, occupation, or profession to be done. The important thing that becomes an aspect for a profession, namely professional attitude and quality of work. Being professional means being an expert in the field. For an organization, management is the key to success, because it determines the smooth performance of the organization concerned as well as in the world of guidance and counseling

Guidance and counseling is an integral part of education that is inseparable, both the theory and practice of the service are dynamic and growing. Along with the development of the sciences that provide donations and along with the development of human culture support the guidance and counseling services itself. Guidance and counseling are held in schools as part of the overall school business in order to achieve educational goals. As a sub-system of education in schools, guidance and counseling in its implementation are never separated from careful and systemic planning (Zamroni \& Rahardjo, 2015: 1)

The process of guidance and counseling services in schools is the most important process because of where there is a direct interaction between teachers guidance and counseling with learners. Therefore guidance and counseling need to have a position and a strategic role in addressing various problems today. Guidance and counseling services in schools are also still subject to many problems at the praxis level. BK teachers as counselors at school still experience various obstacles and problems, the causes of problems can arise from various factors, so only a few schools are able to run BK properly (Anggraini, 2017: 333)

The paradigm of life in the global era, requires learners to have the competence of life to develop effectively, productively and beneficially and benefit themselves and the environment and have high quality (Caraka, Nindiya \& Fuad, 2016: 573). In the perspective of guidance and counseling, learners are individuals who are in the process of developing or becoming, developing into maturity or independence (Bhakti, 2015: 93).

One of the preventive efforts that teachers can do guidance and counseling in developing the maturity or independence is through core curriculums. According to Joseph (2009: 77) guidance included in the core curriculum defined as the process of providing assistance to all students(for all)through the core curriculum activities or groups that presented systematically in order to help the development of learners optimally. core curriculum is also an effective way for counseling and counseling teachers or counselors to provide students with information and/or orientation about school services, advanced education, study skills, and counseling services can be used as preventive services and core curriculum is the part that has the largest share of guidance and counseling services, and is an efficient service, especially in handling the problem of the ratio of the number of counselors and counselors (Farozin, 2012: 143).

In the process of implementation of core curriculums guidance and counseling teachers need to have good service management, so that the process and objectives set can be achieved well too, because basically core curriculum is a service composed of component context, input, process, output, and outcomes. In this section formed sub-sub systems that synergistically support each other in achieving the objectives of the implementation of the program of core curriculums itself. However, in fact based on interviews conducted by Ulfi Lathifah in 2017 with school counselor in junior high school in Yogyakarta showed that the implementation of core curriculum has not run optimally. This is because there is no scheduled school hours for school counselors. In addition, the number of school counselors in the school there is only one school counselor who teach all students in the school that is as many as 12 classes. This is not in accordance with the standard ratio of school counselors based on Permendikbud No. 111 of 2014 which states that the ideal ratio of school counselors with learners is 1: 150 students

Based on the above, the management in the core curriculum is a necessity that must be done by teachers and counseling at school. The first reason for the need for management in core curriculums is that the activities in the core curriculums lead to the goals and the achievement of those goals are always expected to be qualified. The achievement of a quality goal requires a quality process as well. Quality processes can occur when managed in quality. In a very simple management can be translated as the process of managing an activity for the established goal is achieved. The need for quality (processes and outcomes) is the reason for management in many ways, as well as in core curriculums

The second reason is the need for management is in the process of guidance and counseling services requiring human involvement and other resources (in large quantities) to achieve the goal. Moreover, large resources need to be managed in quality so that the dynamics of efficient institutions (resources are sacrificed in accordance with the desired results) and effective (the goal is achieved in quality). The need for efficient and effective core curriculums for the welfare of the counselee is an 
important reason for core curriculum in schools requires administrative (management). The need for administrating and organizing core curriculums in schools refers to the principles of guidance and counseling services as follows (Santoadi, 2010: 9):

1. The primary concern of guidance and counseling is the personal development of the individual human beings served. Personal attention has implications for the provision of serious guidance and counseling services and involves anyone who has the potential to help the counselee grow intact. Therefore, it takes a serious administrating and organizing

2. Guidance and counseling is part of the process of continuing education (continuous) and sequential(sequential). Ongoing and consecutive guidance for the benefit of the counselee, obviously requires serious organizing and administration

3. All students are entitled to counseling services, whether students are problematic or not, so that all students have the opportunity to develop the same optimally. This principle implies that guidance and counseling services are evenly distributed in all functions (curative, preventive, developmental, preservative). Equity of all counseling functions in a comprehensive guidance and counseling program requires good administration.

Thus management in core curriculums can be interpreted as cooperative business control activities to assist learners in addressing the problems and difficulties experienced and held by professional guidance officers with other parties inside and outside the school so that students experience growth and development in a powerless and successful use in achieving their respective goals.

Therefore, to support the role of counselor or teacher guidance and counseling in providing core curriculums in schools, which are effective and efficient, especially in terms of management of core curriculums, here the author offers the idea of management core curriculums based Authentic Instructional Model, which is a management core curriculums that relatively depict the process of implementing the service through the application of knowledge in the context of life and real situations.

Management core curriculum based Authentic Instructional model is a pedagogical approach that places the learning task in context for future use and authentic implementation design has given the imagination to innovative educators who see this approach as a means of enabling learners to

\section{Dipublikasikan Oleh :}

UPT Publikasi dan Pengelolaan Jurnal

Universitas Islam Kalimantan Muhammad Arsyad Al-Banjari Banjarmasin 
management is "to achieve the goals and objectives and subjects that have been governed by the use of people as executors". This is reinforced by Hersey \& Blachard (in Ardhi, 2015) suggests: "We shall define management as working with and through individuals and groups to accomplish organizational goals". Thus, this management requires resources which act as principals in running a thing.

From the definition of management, then when coupled with guidance and counseling which is an important part of education, management is inseparable. Management can be likened to a "spirit" that will move the life-sports movement (Diana, 2012). Therefore management is closely related to guidance.

As the management carried out several activities. According to Terry (in Ardhi, 2015) explains: "management is a distinct process of consisting of planning, organizing, actuating, and controlling, performed to determine and accomplish stated objectives by the use of human being and other resources". As for more detail related to management in guidance. Counseling and guidance management consists of Planning, Organizing, Actuating, and Controlling (Su'ainah, 2017). The activity is a series in guidance management.

Furthermore, functionally according to Sugiyono (in Hana, 2016) described management function at least includes four things: (a) planning, (b) organizing, (c) Actuating and (d) Supervision (controlling). This is clarified by Sugiyono (2011) management guidance and counseling is the management, which is an activity that begins from the planning of guidance and counseling activities, organizing activities and all the supporting elements of guidance and counseling. This is done so that the core curriculums provided to the students are better. The description of each management activity in the core curriculum.

In the first stage of preparation and planning. Certainly, in the management of core curriculum, counselors or school counselors need to pay attention to several things in service preparation and planning. According to Myrick, school counselors create units based on developmental needs and interests, creating sequential units and lessons (Akos, 2007). Thus, organized and managed services need to be based on student needs and development. this can be obtained from the assessment of student needs.

As for the needs assessment of students, counselor or school counselor needs to do several things. (1) Identify data needed for service program preparation, (2) Selecting data collection instruments as needed, (3) Collecting, Processing, Analyzing, and Interpreting Data on Needs Assessment Results (Kemendikbud, 2016). These things need to be done in assessing student needs.
Then, after assessing the needs of the students, it is necessary to determine the needs that the student needs. In determining the needs of students, there are several points emphasized: a) Readiness, which is related to current student knowledge, understanding, abilities and matters relating to student learning. b) Interest, which is related to the interests, or talents of students. this will motivate students to learn. c) Learning Profile, or student learning profile which emphasizes student learning style, intelligence, gender, and culture (Akos, 2007). From here, the needs of students become the foundation in planning the core curriculums that will be arranged in the program either a year or even a semester.

Then go to phase two of the implementation. At the implementation stage of the core curriculum, several activities are carried out: implementing services on schedule, documenting services, recording events or things that need improvement. These things are done in the implementation activities.

Then the last stage is evaluation and report. In doing this evaluation, there are two types of evaluation process and evaluation of results. Process evaluation is an evaluation activity undertaken through analysis of the results of the process assessment during the ongoing guidance service activities. Meanwhile, evaluation of the results to determine the effectiveness of the service. In the evaluation of achievement results are seen, selfunderstanding, attitudes and behaviours obtained by students, then positive feelings, as well as planning the next activity after the post-activity.

From here, guidance management, especially core curriculum is done with various sequences of systematic activities. This is to realize the effective and efficient core curriculums implemented in the classroom. It is important for counselors to organize and manage classes dynamically (Geltner, 2005). Thus the services provided will be acceptable to the student.

\section{The Concept of Authentic Instructional Model}

Authentic Instructional model is a pedagogical approach that places the task of learning in the context of future use, authentic design implementation has given the imagination to innovative educators who see this approach as a means to enable learners to develop strong knowledge and switch or transformed from information into realworld practice. There are four main components found in the authentic instructional model. The four components that support core curriculum based authentic instructional management model are (Luna, 2015: 3):

1) Real World Connection is a component that deals with activities that involve real-world problems and mimics the work of professionals. 2) Critical Thinking ie components related to the use of 
open questions, thinking skills and metacognition. 3) Public Service in this component students engaged in social activities and social learning in a community of learners. 4) Autonomy in this component students are asked to direct their own learning in a job.

The Authentic instructional model also takes into account several other components, which are capable of supporting the achievement of predetermined objectives. The following are the implications of the component authentic instructional model (Tauhidi, 2003: 23) :

1.Spiritual: spiritual awareness is the starting point and basis of the concept of the authentic instructional model. Focuses on the spiritual aspect of child development. From history, we know that spirituality can serve as an important and powerful element in the life of an individual or a society

2.Moral: a noble character is the second component of the conceptual authentic instructional model this and focuses on the moral development aspect of the child. The focus of this part of the program is to develop a strong understanding of good character and help learners to achieve in their personal lives by adopting a moral lifestyle.

3.Intellectual: focuses on the intellectual aspects of child development. This component focuses on developing learners in the love of learning, training them in learning ways and other habits of the mind. Integrated content knowledge from various disciplines and training in critical thinking as well as other problem solving is an important element of this part of the program.

4.Physical:health is the fourth major component and focuses on aspects of physical development. The purpose of this healthy life program component emphasizes that physical and psychological health is an important part of the overall development of humanity and highlights that our body is a perfect system designed.

5.Interpersonal: Interpersonal Relationships. is the fifth component of this concept, focusing on the emotional and interpersonal aspects of child development. The purpose of this interpersonal component is how to build good human relationships.

6.Cultural: focuses on lifestyle and culture as part of human development. How we live, that is our lifestyle, is the clearest reflection of who we are and what we really believe, both individually and as a society

7.Social: social service is the seventh and top component of this model. Focusing on the social aspect of child development, is the culmination of student learning in all areas of character education as well as the application of the values that have been taught.

So based on the above explanation regarding the concept of the authentic instructional model can provide an overview to the teacher guidance and counseling to devise, design and implement core curriculum more creative, innovative and sustainable and developmental

\section{Implementation of Management Core Curriculum Based Authentic Instructional Model}

A guidance and counseling service program is unlikely to be created, implemented and achieved if it does not have a quality management system (carried out clearly, systematically and directed). Management can be said as a process of planning, organizing, leadership and supervision of all members of the organization (group) and the utilization of all organizational resources to achieve the organization's stated goals (Bachrie, 2013: 19)

According to Juntika Nurihsan (2005) management aspects of guidance and counseling service programs are: (1) Program Planning and Timing of Guidance and Counseling Implementation, (2) Organizing Guidance and Counseling, (3) Implementation of Guidance and Counseling Activities, (4 ) Utilization of Supporting Facilities for Guidance and Counseling Activities, (5) Working Mechanisms for Administrating Guidance and Counseling Activities, and (6) Direction, Supervision and Assessment of Guidance and Counseling Activities.

.In implementation management of core curriculum based on Authentic Instruction Model, of course, done through several stages and activities. Basically, management begins with planning, organizing, direction/implementation, and monitoring. However, what differs in this management is from the aesthetics of service-making. In the preparation of the service, there are several things to note.

Where prior to the establishment of a core curriculum, it is necessary to know the effectiveness and achievement of the objectives of the prior service. This is done as an evaluation of service development. Certainly in evaluating should see some things which customize Authentic Instructional Model itself. Is in line with Real World Connection, their Critical Thinking, Public Service, and Autonomy.

After knowing the suitability of the previous service with Authentic Instructional Model. then the service can be improved and adjusted, it can be from the purpose, the method of service implementation, the material and some other things. This is done for services that have been implemented before.

For services to be composed, of course directly leads to the purpose of service. Where to go 
from the core curriculum. Is targeting in terms of social, culture, intrapersonal, intelligence and so forth. Then the core curriculums provided need to be structured to engage with the real world, be able to increase critical thinking, get students involved in social activities and so forth.

For example services: core curriculum which invites students to social service, this is to foster a sense of care and social relationships. Surely in this activity already involves components in Authentic Instructional Model. This service is related to the real world and certainly helps others, and students will think about what is needed and be of concern to the recipients of social services.

Thus, the service is in conformity with the Authentic Instructional Model. Then the service can be compiled into work program for guidance and counseling services, RPL and applied to students. It is hoped that the services will be based on Authentic Instructional Model., not only the potential that is developed in students, but there are essence and meaning in the learning process.

\section{CONCLUSION}

Core curriculums are fundamental to the provision of counseling and guidance services in schools. This is because the core curriculum is provided to all students. Certainly, in providing effective core curriculums, require good management or service management as well. Management becomes key in the preparation of core curriculums. Of course, the current need to evaluate whether the management of core curriculum is done now in accordance with the achievements to be achieved. From here, the need to continue to optimize the management of existing core curriculum.

Authentic Instructional Model is one of the models that put the task of learning in context for future use, authentic design implementation has given the imagination to innovative educators. In the Authentic Instructional Model, emphasizing various aspects such as meaning, student engagement, and various other things. This model can be the foundation and can be used in the management of core curriculums. With Authentic Instructional Model, it is expected that the service is designed and managed not only to design and execute but also pay attention to detail and usefulness as well.

Certainly, the management of core curriculums using Authentic Instructional Model effectively requires the support of various parties such as the principal as responsible and necessary to know the service development, the coordinator of school counselor as observers of service achievements, and observers in the process of design and management of core curriculums using Authentic Instructional Model.

\section{REFERENCE}

Akos , Patrick \& Caroline R.Cockman , Cindy A.Strickland. (2007). Differentiating Classroom Guidance. Professional School Counseling, 10 (5), 455-463

Anggraini, S. (2017). Peran Supervisi BK Untuk Meningkatkan Profesionalisme Guru BK. In Prosiding Seminar Bimbingan dan Konseling (Vol. 1, No. 1, pp. 332-341).

Ardhi, Mohammad Imam. (2015). Evaluasi Manajemen Penerimaan Peserta Didik Baru Sistem Real Time Online Dinas Pendidikan Kota Yogyakarta. Jurnal Penelitian Ilmu Pendidikan. 8 (1), 80-94

Arviani, Sari \& Denok Setiawati. (2018). Pemanfaatan Wayang Profesi Dalam Bimbingan Klasikal Untuk Meningkatkan Wawasan Dan Kesiapan Karir Kelas Olahraga (Vii-A) Di Smpn 3 Gresik. Jurnal BK UNESA, 8(1)

ASCA. (2016). The ASCA National Model Implementation Guide: Foundation,Management and Accountability. Alexandria, VA: Author

Bhakti, C. P. (2015). Bimbingan Dan Konseling Komprehensif: Dari Paradigma Menuju Aksi. Jurnal Fokus Konseling, 1(2), 93-106.

Bachrie, S. (2013). Pengembangan Manajemen Bimbingan dan Konseling Berbasis ICT. PSIKOPEDAGOGIA Jurnal Bimbingan dan Konseling, 2(1), 14-28

Caraka, P. B., Nindiya, E. S., \& Fuad, A. R. (2016). Improving Quality Of Education Through Collaboration System In The Perspective Of Comprehensive Guidance And Counseling. (pp. 573-578). Malang: Universitas Negeri Malang

Fandini, Shella Hario \& Budi Purwoko. (2018). Pengembangan Adobe Flash Sebagai Media Layanan Informasi Peminatan Studi Lanjut Sma Dan Sederajat Untuk Siswa Kelas Ix Smpn 5 Sidoarjo. Jurnal BK UNESA, 8(1)

Farozin, M. (2012). Pengembangan Model Bimbingan Klasikal untuk Meningkatan Motivasi Belajar Siswa SMP. Cakrawala Pendidikan, (1), 143156. Yogyakarta: Universitas Negeri Yogyakarta

Geltner, Jill A. \& Mary Ann Clark. (2005). Engaging Students in Classroom Guidance:Management Strategies for Middle School Counselors. Professional School Counseling, 9 (2), 164-166

Hana, Nafisatul \& Catharina Tri Anni. (2016) .Studi Deskriptif Penggunaan Software IKMS® Dalam Perencanaan Manajemen Bimbingan dan Konseling . Indonesia journal of Guidance and Counseling: Theory and Application. 5(1), $51-56$

Jafar, Djailani AR, \& Khairuddin. (2016). Manajemen Pendidikan Dayah Nurul Kecamatan Peudada 
Kabupaten Bireuen. Jurnal Administrasi Pendidikan Pascasarjana Universitas Syiah Kuala. 4(1), 56-62

Juntika Nurihsan, A. (2005). Strategi Layanan Bimbingan dan Konseling, Bandung: PT Refika Aditama

Kementerian Pendidikan dan Kebudayaan Direktorat Jenderal Guru dan Tenaga Kependidikan. (2016). Panduan Operasional Penyelenggaraan Bimbingan dan Konseling Sekolah Menengah Pertama. Jakarta

Lathifah, U. (2017). Upaya Meningkatkan Pemahaman Siswa Tentang Faktor Penyebab Perilaku Bullying Melalui Layanan Bimbingan Klasikal Pada Siswa Kelas IX D di SMP Negeri 11 Yogyakarta Tahun 2017/2018 (Skripsi Tidak Terpublikasi). Sarjana Fakultas Keguruan dan Ilmu Pendidikan Universitas Ahmad Dahlan, Yogyakarta.

Luna Scott, C. (2015). The Futures Of Learning 3: What Kind Of Pedagogies For The 21st Century?. United Nations Educational, Scientific And Cultural Organization

Nirva Diana. (2012). Manajemen Pendidikan Berbasis Budaya Lokal Lampung (Analisis Eksploratif Mencari Basis Filosofis). Analisis. 12 (1), 183208

Nur, Muhammad \& Cut Zahri Harun, Sakdiah Ibrahim. (2016). Manajemen Sekolah Dalam
Meningkatkan Mutu Pendidikan Pada Sdn Dayah Guci Kabupaten Pidie. Jurnal Administrasi Pendidikan Pascasarjana Universitas Syiah Kuala. 4(1), 93-103

Peraturan Menteri Pendidikan dan Kebudayaan RI Nomor 111 Tahun 2014 tentang Bimbingan dan Konseling Pada Pendidikan Dasar dan Pendidikan Menengah

Purwanto, N., (2013). Administrasi dan Supervisi pendidikan. Bandung: Rosda Karya.

Santoadi, F. (2010). Manajemen Bimbingan dan Konseling Komprehensif. Yogyakarta: Universitas Sanata Dharma.

Su'ainah, Aliman, \& Osa Juarsa. (2017). Manajemen Bimbingan Dan Konseling Di Sma. Manajer Pendidikan. 11 (3), 287-296

Sugiyono. (2011). Manajemen bimbingan dan konseling di sekolah. Semarang: Widya Karya Semarang

Suharsimi. (2012). Manajemen Pendidikan. Yogyakarta: Aditya Media \& FIP UNY

Tauhidi, Dawud. (2003). The Tarbiyah Project an Overview. Philadelphia: Education for Total Human Development

Zamroni, E., \& Rahardjo, S. (2015). Manajemen Bimbingan Dan Konseling Berbasis Permendikbud Nomor 111 Tahun 2014. Jurnal Konseling Gusjigang, 1(1). 